DOI: $10.17951 / f f .2019 .37 .2 .133-142$

\begin{tabular}{lcr}
\hline \multicolumn{2}{c}{ A N N A LES } \\
\multicolumn{2}{c}{ UNIVERSITATIS M A R I A E C URIE - S KŁ O D O W S K A } \\
LOL. XXXVII & LU B L I N - P O L ONIA \\
\hline
\end{tabular}

\author{
LIUBOV OSTASH \\ Ivan Franko National University of Lviv, Ukraine \\ ORCID ID: https://orcid.org/0000-0001-8785-7442 \\ e-mail: ostash@seznam.cz
}

\title{
Ukrainian First Names in the Anthroponymic Space of the Czech Republic
}

Imiona ukraińskie w przestrzeni antroponimicznej Republiki Czeskiej

The issue of the Ukrainian first names in the anthroponymic space of the Czech Republic is quite extensive and comprises many questions. In our article, the attention has been focused on one of the issues: how the Ukrainian first names have been presented in Czech onomastic papers, in particular, in the Czech anthroponymic dictionary Jak se bude vaše dítě jmenovat? by the famous Czech scholar Miloslava Knappová (2017). Its latest edition includes 17,000 Czech and foreign-language forms of first names. In the lexical entries, the author provides Ukrainian correspondences among other foreign-language parallel forms. Any of these first names (be it Czech or foreign-language form) may be chosen by parents for their child (if this first name is included in the dictionary, it is a legitimate ground for the official name record). In some specific cases (if the first name is not included in the dictionary by Knappová), parents may enquire Knappová or the Department of Onomastics of the Institute of the Czech Language of the Academy of Sciences of the Czech Republic for official expertise.

The issue of Ukrainian first names in the Czech Republic is even more complicated because Cyrillic is used in the Ukrainian language, while in the Czech language, the Roman alphabet is used. The rules of the Czech orthography provide the principles to transliterate the Ukrainian proper names, written in Cyrillic, by means of the Czech graphemes (Pravidla českého pravopisu, 2012, pp. 77-80). These rules are quite effective in transliterating Ukrainian first names, so they may be used as a reliable guide. 
Our research deals with the analysis of the first names, which are presented as the Ukrainian ones, in the above-mentioned dictionary. By and large, we have found 409 Ukrainian male names and 271 Ukrainian female names. In our analysis the Ukrainian dictionaries of first names, namely Власні імена людей by Larisa H. Skripnik and Nina P. Dzâtkìvs'ka (2005), Словник украӥнських імен by İvan I. Trìjnâk (2005), Слов'янські особові імена украӥнців by Pavlo Čučka (2011) have been used.

305 male names and 215 female names, which are represented as the Ukrainian equivalents in the Czech dictionary (Knappová, 2017), have been recorded in the Ukrainian dictionaries and comply with the rules of the Ukrainian orthography (examples are provided as they are spelt in Czech):

The male names: Abram, Adam, Adolf, Adrian, Afanasij, Achilla, Achillij, Albert, Alfred, Amadej, Ambrosij, Amos, Amvrosij, Ananij, Anastas, Anastasij, Anatol, Anatolij, Andrian, Andrij, Andron, Andronyk, Antin, Anton, Antonij, Antonin, Arkadij, Armenij, Arnold, Artem, Artemij, Arsen, Arsenij, Atanas, Atanasij, Avel, Averkij, Avram, Avrelij, Baltasarij, Bartolomij, Blahoslav, Blažij, Bohdan, Bohuslav, Bojan, Boleslav, Bonifatij, Borys, Bronislav, Budymyr, Danylo, Darij, Davyd, Demjan, Denys, Dmytro, Dobroslav, Dorofij, Edmund, Emil, Emilian, Erazm, Ernest, Ernst, Fabian, Fadej, Favst, Fedir, Fedosij, Feliks, Feodosij, Feodul, Feofan, Feofil, Fidel, Flavij, Foma, Fortunat, Fot, Fotij, Franc, Fridrich, Fylymon, Harasym, Havrylo, Charytin, Charyton, Choma, Chrystofor, Ihor, Illja, Inokentij, Ipolyt, Ivan, Jakiv, Jakub, Jakym, Jan, Jarema, Jaromyr, Jaroslav, Jeleazar, Jevarest, Jevstachij, Josyp, Julian, Julij, Jurij, Justym, Justyn, Kalenyk, Kalistrat, Kapiton, Karl, Karlo, Karpo, Kasjan, Kazymyr, Kesar, Klavdij, Klym, Klyment, Klymentij, Konrad, Kornelij, Ksaverij, Kuprij, Kuprijan, Kyr, Kyriak, Kyrian, Kyrjak, Kyrjan, Kyrylo, Lavrentij, Lavrin, Lavro, Lazar, Leon, Leonard, Leonid, Leontij, Leopold, Lev, Ljubomyr, Luka, Lukij, Lukjan, Makar, Maksym, Marian, Markel, Markelo, Markijan, Marko, Matvij, Mavr, Mefodij, Melentij, Meletij, Mojsej, Mstyslav, Musij, Mychajlo, Mychej, Mykola, Myron, Myroslav, Natan, Nazar, Nazarij, Nyčypir, Nykin, Nykodym, Nykon, Nykyfor, Ochrim, Olefir, Oleh, Oleksandr, Oleksij, Omeljan, Onysij, Onysyfor, Onysym, Orest, Orfej, Oskar, Ostap, Osyp, Ovdij, Overkij, Ovram, Pachom, Pankrat, Pankratij, Pantelej, Pantelejmon, Pantelemon, Pavlo, Petro, Platon, Polikarp, Porfyr, Porfyrij, Prochor, Prokip, Prokopij, Protas, Protasij, Pylyp, Radomyr, Radoslav, Rajmond, Rodion, Rolan, Roland, Roman, Rostyslav, Rudolf, Ruslan, Sava, Savel, Savelij, Savka, Selinij, Semen, Serafym, Serapion, Sever, Severjan, Severyn, Sevir, Slava, Slavmyr, Slavomyr, Sofron, Solomon, Sopron, Sozon, Sozont, Stanislav, Stasij, Stepan, Stojan, Straton, Svitozar, Svjatoslav, Svyryd, Svyrydon, Sydir, Sylvestr, Symon, Tadej, Taras, Teodor, Teofan, Teofil, Terentij, Todor, Trochym, Tryfilij, Tryfon, Tychin, 
Tychon, Tymko, Tymofij, Tymon, Tymur, Tyt, Uljan, Urban, Urvan, Ustym, Ustyn, Vaclav, Vadym, Valentij, Valentyn, Valerian, Valerij, Valerjan, Varfolomij, Varvar, Vasyl, Venedykt, Veniamin, Viktor, Viktorij, Viroslav, Vitold, Vjačeslav, Vladyslav, Vojtech, Volodymyr, Vseslav, Zachar, Zacharij, Zakchej, Zenon, Zinovij, Zorian, Zorjan, Zosym.

The female names: Ada, Adelina, Adriana, Afanasija, Afina, Albina, Alfreda, Alina, Alisa, Anatolija, Anhelina, Anna, Antonija, Antonina, Apollonija, Ariadna, Artemija, Atena, Avrora, Bella, Berta, Boleslava, Bronislava, Cecilija, Celestyna, Darija, Daryna, Dina, Dora, Dorofeja, Doroteja, Emilija, Emma, Erna, Esfir, Ester, Fedora, Felicata, Feliksa, Feofila, Florentyna, Franka, Frosyna, Halyna, Hanna, Hortenzija, Ida, Ilarija, Ilona, Inna, Irma, Iryna, Isydora, Ivanna, Izabella, Izolda, Jaryna, Juliana, Julija, Julyna, Justyna, Juzefa, Kamila, Karolina, Karyna, Kateryna, Katrja, Kira, Klara, Klarysa, Klavdija, Klementyna, Kleopatra, Konstancija, Kornelija, Lada, Larysa, Laura, Leja, Leonila, Leontyna, Lesja, Liana, Lidija, Liliana, Lilijana, Lina, Ljubomyla, Ljubomyra, Ljubov, Ljucija, Mahdalyna, Majja, Malva, Malvina, Marfa, Marharyta, Mariamna, Marianna, Marija, Marjana, Marta, Matylda, Melana, Melanija, Mlada, Mychajlyna, Mylana, Myloslava, Mylycja, Myra, Myronija, Myroslava, Nadija, Nastasija, Natalija, Natalja, Nelja, Nelli, Nika, Nila, Nina, Ninel, Oksana, Oleksandra, Olena, Olesja, Olha, Olimpiada, Olimpija, Oljana, Oresta, Oryna, Palmyra, Paraska, Paraskeva, Paraskovija, Pavla, Pavlyna, Petrana, Petrunelja, Poliksena, Poliksenija, Polina, Priska, Pulcherija, Rada, Rafalyna, Rachilja, Rajmonda, Renata, Roksana, Roksolana, Romana, Romanija, Rostyslava, Roza, Rozalija, Ruf, Ruslana, Ružena, Sabina, Sara, Savina, Sevastiana, Silva, Silvija, Solomija, Stanislava, Stefanyda, Stella, Stepanija, Stepanyda, Susanna, Svitlana, Svjatoslava, Tamara, Tekla, Teodora, Teodozija, Teodozja, Teofila, Teofilija, Tereza, Terezija, Tet'ana, Uljana, Valentyna, Valerija, Vanda, Varvara, Vasylyna, Venera, Veronika, Viktorija, Viktoryna, Viola, Violetta, Vira, Viroslava, Vita, Vitalija, Vjačeslava, Vlada, Vladlena, Vladylena, Vladyslava, Vlasta, Volodymyra, Zlata, Zlatoslava, Zoja, Zorja, Zorjana, Zoryna.

At the same time, we would like to draw attention to some problems which arise during the transliteration of the Ukrainian first names by means of the Czech graphemes.

In some first names, the Ukrainian 2 is transliterated by the letter $g$, though the rules of the Czech orthography recommend to transliterate the Ukrainian 2 by the letter $h$ (Pravidla českého pravopisu, 2012, p. 80). It concerns, in particular, the following first names:

The male names: Agafon, Agafonik-Ukr. Агафон, Агафоник; Avgustin-Ukr. Августин; Bogdan (also Bohdan) - Ukr. Богдан; Egydij - Ukr. Сгидій; Gennadij - Ukr. Геннадій; Georgij - Ukr. Георгій; Ignat, Ignatij - Ukr. Ігнат, Ігнатій; 
Jegor - Ukr. Єгор; Ogej - Ukr. Oгей; Ogij - Ukr. Oziü; Sergij - Ukr. Cергiŭ; Svjatogor - Ukr. Святогор.

The female names: Agata - Ukr. Azama; Aglaja - Ukr. Aглая; Avgusta - Ukr. Августа; Bogdana - Ukr. Богдана; Boguslava - Ukr. Богуслава; Ganna (also Hаnna) - Ukr. Ганна; Gustava - Ukr. Густава; Inga - Ukr. Інга; Pelageja - Ukr. Пелагея; Pеlagija - Ukr. Пелагія; Regina - Ukr. Регіна; Virginija - Ukr. Віргінія.

According to the Ukrainian orthography, these first names should be transliterated with $h$ : the male names: Ahafon, Ahafonyk, Avhustyn, Bohdan, Jehydij, Hennadij, Heorhij, Ihnat, Ihnatij, Jehor, Ohej, Ohij, Serhij, Svjatohor; the female ones: Ahata, Ahlaja, Avhusta, Bohdana, Bohuslava, Hanna, Hustava, Inha, Pelaheja, Pelahija, Rehina, Virhinija.

Sometimes during the transliteration of the Ukrainian first names by means of the Czech graphemes, the problems of rendering letters $u$ and $i$ arise. To transliterate the Ukrainian $u$ into the Czech language, the rules of the Czech orthography recommend to use the letter $y$; to transliterate the Ukrainian $i$ - the Czech letter $i$ (Pravidla českého pravopisu, 2012, p. 80). We consider there rules to be effective. Most first names in the Czech dictionary are presented according to this principle, for example: Denys - Ukr. Денис; Jakym - Ukr. Яким; Lavrin - Ukr. Лаврін; Jevstachij-Ukr. Cвcmaxiü; Nyčypir - Ukr. Hичunip. In our opinion, this principle should have been applied in the transliteration of the following first names:

The male names: Archip - a better version is Archyp (Ukr. Apxun); Agafonika better version is Ahafonyk (Ukr. Агафоник); Avgustin - a better version is Avhustyn (Ukr. Августин); Benedikt, Venedikt - better versions are Benedykt; Venedykt (Ukr. Бенедикт, Венедикт); Bohитіl - a better version is Bohumyl (Ukr. Богумил); Borislav - a better version is Boryslav (Ukr. Борислав); Irinij - a better version is Irynij (Ukr. Іриній); Jelizar - a better version is Jelyzar (Ukr. Слизар); Fotin - a better version is Fotyn (Ukr. Фотин); Francisk - a better version is Francysk (compare Ukr. францисканці / frantsyskantsi [Ševčenko, 2008, p. 638], францисканець / frantsyskanets, францисканський / frantsyskanskyi [Rusanìv'kij, 2006, p. 897]); Kir, Kirilo - better versions are Kyr, Kyrylo (Ukr. Кир, Кирило); Martin - a better version is Martyn (Ukr. Мартин); Martinian - a better version is Martynian (Ukr. Мартиніан); Maximilian - a better version is Maksymilian (Ukr. Максиміліан); Mečislav - a better version is Mečyslav (Ukr. Мечислав); Mikola, Mikolaj, Nikola - better versions are Mykola, Mykolaj, Nykola (Ukr. Микола, Миколай, Никола); Milan - a better version is Mylan (Ukr. Милан); Milij - a better version is Mylij (Ukr. Милій); Miloslav - a better version is Myloslav (Ukr. Милослав); Miroslava better version is Myroslav (Ukr. Мирослав); Osip - a better version is Osyp (Ukr. Ocun); Parfenyj - a better version is Parfenij (Ukr. Парфеніü); Pavlin - a better version is Pavlyn (Ukr. Павлин); Radim - a better version is Radym (Ukr. Paдим); 
Radivon - a better version is Radyvon (Ukr. Радивон); Salivon - a better version is Salyvon (Ukr. Саливон); Simon - a better version is Symon (Ukr. Симон); Vitalyj - a better version is Vitalij (Ukr. Віталій).

The female names: Albertina - a better version is Albertyna (Ukr. Альбертина); Antonida - a better version is Antonyda (Ukr. Антонида); Beatrisa - a better version is Beatrysa (Ukr. Беатрuca); Kikilija - a better version is Kykylija (Ukr. Кикилія); Denisija - a better version is Denysija (Ukr. Денисія); Fylomena a better version is Filomena (Ukr. Філомена); Josipa - a better version is Josypa (Ukr. Йосипа); Osipa - a better version is Osypa (Ukr. Ocuna); Kazimira - a better version is Kazymyra (Ukr. Казимира); Chrystina - a better version is Chrystyna (Ukr. Христина); Marina - a better version is Maryna (Ukr. Марина); Mečislava - a better version is Mečyslava (Ukr. Мечислава); Orina - a better version is Oryna (Ukr. Орина); Petrina - a better version is Petryna (Ukr. Петрина); Serafima a better version is Serafyma (Ukr. Серафимa); Ulita - a better version is Ulyta (Ukr. Улита); Ustina - a better version is Ustyna (Ukr. Устина).

Another issue concerns the palatalized Ukrainian consonants. Unfortunately, it is not always possible to represent palatalization of consonants by means of the Czech graphemes. The Ukrainian first name Кузьмa, for example, is transliterated into the Czech language as Kuzma, the Ukrainian Cmacb - as Stas. In these cases, it is difficult to offer any reliable method to render consonant palatalization, which the Czech readers can easily understand. However, in other cases, like Kostjantyn (Ukr. Костянтин), Sevastjan (Ukr. Севастян), Chrystja (Ukr. Христя), Sevastjana (Ukr. Севастяна), Kost'antyn, Sevast'an, Chryst'a, Sevast'ana would be better variants. A better version of transliteration for the first name Pюрик would be Rjuryk instead of Ruryk; and the version of Martjan (instead of Martjan) would be better for the first name Мартьян.

The Ukrainian letter $\epsilon$ should be represented with the letter-combination je, that is why the Ukrainian male names Свген, Свгеній, Свникій, Сфрем, Свстахій, Сгидій, Сзекія would be better transliterated as Jevhen, Jevhenij, Jevnykij, Jefrem, Jevstachij, Jehydij, Jezekija instead of Evhen, Evhenij, Evnykij, Efrem, Evstachij, Egydij, Ehidij, Ihidij, Ezekija. The female names Слизавета, Сфросинія, Свлалія, Сва, Свгенія would be transliterated as Jelyzaveta, Jefrosynija, Jevlalija, Jeva, Jevhenija instead of Elyzaveta, Efrosynija, Evlalija, Eva, Evgenija.

The phenomenon of iotation in the Ukrainian first names should be represented in the following cases:

The male names: Emmanuil - a better version is Emmanujil (Ukr. Eммануїл); Iеremija - a better version is Ijeremija (Ukr. Іеремія); Iеron - a better version is Ijeron (Ukr. Іерон); Iеronim - a better version is Ijeronim (Ukr. Іеронім); Iezekiil, Ezekiil - better versions are Ijezekijil (Ukr. Ієзекіїль), Jezekijil (Ukr. Єзекіїль); 
Izmail - a better version is Izmajil (Ukr. Iзмаїл); Manuil - a better version is Manujil (Ukr. Мануїл); Rafail - a better version is Rafajil (Ukr. Paфаїл).

The female names: Adelaida - a better version is Adelajida (Ukr. Aделаїда); Aida - a better version is Ajida (Ukr. Aïda); Iraida - a better version is Irajida (Ukr. Ipaïda); Luiza - a better version is Lujiza (Ukr. Jÿ̈зa); Maina - a better version is Majina (Ukr. Maїнa); Marietta - a better version is Marijetta (Ukr. Mapiemma); Raisa - a better version is Rajisa (Ukr. Païca); Taisa - a better version is Tajisa (Ukr. Taïca), Taisija - a better version is Tajisija (Ukr. Taїсія); Zinaida - a better version is Zinajida (Ukr. Зінаїда).

However, it is recommended not to mark iotation in the following Ukrainian first names: Avrelijan - a better version is Avrelian (Ukr. Авреліан); Flavijan a better version is Flavian (Ukr. Флавіан).

In some cases, technical misprints may be found in transliteration of the Ukrainian first names, for example, the male names: Abdonij - Ukr. Абнодій (Abnodij); Appolinarij - Ukr. Аполлінарій (Apollinarij); Azarija - Ukr. Aзарій (Azarij); Afanas - Ukr. Aтанас (Atanas); Brjacyslav-Ukr. Брячислав (Brjačyslav); Nakrys - Ukr. Наркис (Narkys); the female name Danaila-Ukr. Даниїла (Danyjila).

The Ukrainian female name Анжеліка should be transliterated as Anželika, not Anhelika.

Sometimes forms of first names from other languages are mistakenly considered Ukrainian: for example, Vladimir - Ukr. Володимир (Volodymyr); Artom - Ukr. Артем (Artem); Leonidas - Ukr. Леонід (Leonid).

Some first names, regarded as Ukrainian in the dictionary by Knappová (2017), are not recorded as official names in the Ukrainian dictionaries of first names, namely: the male names Henryk, Herard, Hothard, Iakynt, Illjaš, Ionafan, Kiprij, Kiprijan, Lazo; the female names Hracija, Luize, Marine, Orestina, Estella; Svetislava. The first names Iллям (Illjaš) and Орестина (Orestyna) are recorded as colloquial ones according to the dictionary by Trìjnâk $(2005$, p. 152, 274).

In the Czech dictionary, the male name Lesjan is described as a Ukrainian male name corresponding to the Ukrainian female name Lesja (Knappová, 2017, p. 242). However, we have not found this Ukrainian male name in any Ukrainian dictionaries of first names or in any other sources. In the Ukrainian anthroponymy, the male name Лecb is recorded, however, this first name is not a direct equivalent to the female name Леся (< Лариса, Олександра), but it is a derivative from the male names Олександр, Олесь, Олег (Skripnik and Dzâtkìvs'ka, 2005, p. 72, 84).

The male name Rozumnyk has been marked as Ukrainian in the Czech dictionary (Knappová, 2017, p. 298). Despite the fact that all three Ukrainian dictionaries of names include this first name ([Trìjnâk, 2005, p. 314], the dictionary by Skripnik and Dzâtkìvs'ka treats it as outdated [Skripnik and Dzâtkìvs'ka, 2005, p. 260], and 
the dictionary by Čučka describes it referring to the dictionary by Skripnik and Dzâtkìvs'ka [Čučka, 2011, p. 307]), we have to emphasize that nowadays native speakers of Ukrainian do not associate this word with a first name, but with a common noun.

The Ukrainian first names, recorded in the Czech dictionary, have different frequency of usage in Ukraine. The following first names may be considered as widely-spread (all names are provided with the spelling of the Czech dictionary [Knappová, 2017]): the male names Adrian, Anatolij, Andrian, Andrij, Antin, Anton, Artem, Arsen, Arsenij, Bohdan, Borys, Demjan, Danylo, Davyd, Denys, Dmytro, Fedir, Ihor, Illja, Ivan, Jarema, Jaromyr, Jaroslav, Josyp, Jurij, Kyrylo, Lavrentij, Lavrin, Leonid, Lev, Ljubomyr, Lukjan, Makar, Maksym, Markijan, Marko, Matvij, Mychajlo, Mykola, Myron, Myroslav, Nazar, Nazarij, Oleh, Oleksandr, Oleksij, Orest, Ostap, Pavlo, Petro, Rostyslav, Ruslan, Semen, Severyn, Stepan, Svjatoslav, Tadej, Taras, Vadym, Valentyn, Valerij, Vasyl, Viktor, Vjačeslav, Vladyslav, Volodymyr, Zinovij; the female names Anhelina, Alina, Alisa, Anna, Darija, Daryna, Halyna, Hanna, Iryna, Ivanna, Jaryna, Juliana, Julija, Justyna, Kateryna, Larysa, Lidija, Ljubov, Marharyta, Marija, Marjana, Marta, Maryna, Melanija, Myroslava, Nadija, Natalija, Natalja, Oksana, Oleksandra, Olena, Olha, Polina, Roksolana, Solomija, Svitlana, Tetana, Uljana, Valentyna, Valerija, Varvara, Veronika, Viktorija, Vira, Zlata, Zorjana.

In the Czech Republic there exist some first names which have the specific Ukrainian features. In 2017, the following first names were recorded as used for naming residents in the Czech Republic: the male names: Andrij, Danylo, Denys, Dmytro, Fedir, Havrylo, Ihor, Marko, Josyp, Kyrylo, Ljubomyr, Markijan, Orest-Evhen Mstyslav, Mychajlo, Mykola, Mylan, Myroslav, Nazar, Nazarij, Oleh, Oleksandr, Oleksij, Petro, Rostyslav, Tadej, Vladyslav, Volodymyr, Zorjan, etc.; the female names: Daryna, Halyna, Iryna, Jaryna, Kateryna, Lesja, Ljudmyla, Mahdalyna, Marharyta, Marjana, Myroslava, Nadija, Oksana, Oleksandra, Olena, Olesja, Olha, Roksolana, Svitlana, Tetana, Tetjana, Vasylyna, Volodymyra, Vladyslava, Vira, Zoriana, Zorjana, etc. (Ministerstvo vnitra České republiky, 2017).

Many Ukrainian first names have been recorded in the Czech dictionary of first names. Some more examples should be added, which may appear among the Ukrainian equivalents in the future, namely male names: Ukr. Всеволод (Vsevolod) - Cz. Vsevolod; Ukr. Ждан (Ždan) - Cz. Ždan; Ukr. Зореслав (Zoreslav) - Cz. Zoroslav, Zorislav; Ukr. Радислав (Radyslav) - Cz. Radoslav, Radislav; female names: Ukr. Анастасія (Anastasija) - Cz. Anastázie, Anastasie; Ukr. Божена (Bоžena) - Cz. Božena; Ukr. Дзвенимира (Dzvenymyra) - Cz. Zvonimíra; Ukr. Домініка (Dominika) - Cz. Dominika; Ukr. Євдокія (Jevdokija) - Cz. Evdokie, Eudokie; Ukr. Зіновія (Zinovija) - Cz. Zenobie; Ukr. Зореслава (Zoreslava)-Cz. Zoroslava; 
Ukr. Квітослава (Kvitoslava) - Cz. Květoslava; Ukr. Людмила (Ljudmyla) Cz. Ludmila; Ukr. Лукія (Lukija) - Cz. Lucie; Ukr. Paдислава (Radyslava) - Cz. Radoslava, Radislava; Ukr. Радомира (Radomyra)-Cz. Radomíra; Ukr. Славомира (Slavomyra)-Cz. Slavomíra; Ukr. Coфiя (Sofija)-Cz. Žofie, Sofie; Ukr. Стефанія (Stefanija) - Cz. Štěpána, Štěpánka; Ukr. Яна (Jana) - Cz. Jana; Ukr. Яромира (Jaromyra) - Cz. Jaromíra; Ukr. Ярослава (Jaroslava) - Cz. Jaroslava.

The list of the Ukrainian first names, presented in the Czech dictionary Jak se bude vaše ditě jmenovat? by Knappová (2017), is rich and diverse. It gives the Czech readers an opportunity to get acquainted with the foreign (Ukrainian) anthroponymy, to find out differences and similarities in the sets of first names of the two Slavonic nations - Ukrainians and Czechs. The research of issues of transliterating the Ukrainian first names by the means of the Czech graphemes will contribute to the standardization of their forms functioning in the Czech society.

Translated into English by Diana Kalishchuk

\section{REFERENCES}

Čučka, Pavlo. (2011). Slov'âns 'kì osobovì ìmena ukraïncìv. İstoriko-etimologičnij slovnik. Užgorod: Lìra. [Чучка, Павло. (2011). Слов'янські особові імена украӥнців. Історико-етимологічний словник. Ужгород: Ліра.]

Knappová, Miloslava. (2017). Jak se bude vaše ditě jmenovat? Praha: Academia.

Ministerstvo vnitra České republiky. (2017). Četnost jmen a př́imení. Downloaded from: http://www. mvcr.cz/clanek/cetnost-jmen-a-prijmeni-722752.aspx (access: 05.09.2017).

Pravidla českého pravopisu. (2012). Praha: Academia.

Rusanìvs'kij, Vìtalìj Makarovič (ed.). (2006). Ukraïns'kij orfografičnij slovnik. Kiïv: Dovìra. [Русанівський, Віталій Макарович (ред.). (2006). Український орфографічний словник. Київ: Довіра.]

Skripnik, Larisa Grigorìvna, Dzâtkìvs'ka, Nìna Pantelejmonìvna (2005). Vlasnì ìmena lûdej. Slovnik-dovidnik. Kiïv: Naukova dumka. [Скрипник, Лариса Григорівна, Дзятківська, Ніна Пантелеймонівна. (2005). Власні імена людей. Словник-довідник. Київ: Наукова думка.]

Trìjnâk, İvan İvanovič (2005). Slovnik ukraïns'kih imen. Kiïv: Dovìra. [Трійняк, Іван Іванович. (2005). Словник українських імен. Київ: Довіра.]

Ševčenko, Larisa İvanìvna (ed.). (2008). Novij slovnik ìnshomovnih slìv. Kiïv: Arìj. [Шевченко, Лариса Іванівна (ред.). (2008). Новий словник іншомовних слів. Київ: Арій.]

\section{ABSTRACT}

The problem of the Ukrainian first names functioning in the Czech Republic anthroponymic space is quite extensive and covers many issues. The article is focused on the research of the ways the Ukrainian first names are presented in the Czech onomastic papers, in particular, in the Czech anthroponymic dictionary Jak se bude vaše ditě jmenovat? (2017) by the famous Czech scholar 
Miloslava Knappová. The 2017 latest edition contains 17,000 Czech and foreign-language forms of first names. Parents have the right to choose any of these first names (be it Czech or foreign) for their child, and if this first name is included in the above-mentioned dictionary, it is a sufficient reason for the chosen name official recording. In the lexical entries, the author provides the Ukrainian equivalents among other foreign-language parallel forms. These Ukrainian counterparts, in particular, constitute the main source of our research. Also, in the article, the material recorded in the Ukrainian dictionaries has been used to compare different reference sources. To carry out the analysis of the Ukrainian first names functioning in the Czech anthroponymy, the author has used the linguistic descriptive method, comparative and statistical methods. The problem of the Ukrainian first names functioning in the Czech Republic is complicated by the fact that in the Ukrainian language, Cyrillic is used, and the Czech language uses the Roman alphabet. Principles to transliterate the Ukrainian names, written in Cyrillic, by means of the Czech graphemes are presented in the rules of the Czech orthography. It has been concluded that the rules of the Czech orthography are quite efficient in transliterating the Ukrainian names, so they can be used as a reliable example. In the article, various problems arising when the Ukrainian first names are transliterated using the Czech graphemes have been analysed. In particular, a special attention has been paid to the problem of transliterating the Ukrainian letter 2 in those first names, as well as peculiarities of transliterating the letters $u$ and $i$, and the ways to render palatalization of the Ukrainian consonants. Issues related to transliteration of the Ukrainian letter $\epsilon$ and the general problem of rendering Ukrainian names' iotation have been analysed. The frequency of the studied names' use in the Ukrainian anthroponymy has been studied. Several proposals on possible future expansion of the Ukrainian parallels repertoire in the Czech dictionary of first names have been defined. As a result of the analysis carried out, it has become clear that the repertoire of the Ukrainian first names, represented in the Czech dictionary, is very rich and varied, containing 409 Ukrainian male names and 271 Ukrainian female names. They are registered by the Ukrainian dictionaries of first names and correspond to the Ukrainian spelling of 305 male names and 215 female names.

Key words: first name, dictionary of first names, spelling, Czech anthroponymy, Ukrainian anthroponymy

\section{ABSTRAKT}

Problem funkcjonowania ukraińskich imion w przestrzeni antroponimicznej Republiki Czeskiej jest dość obszerny i obejmuje wiele kwestii. Artykuł ma na celu ustalić, jak ukraińskie imiona są podawane w czeskich pracach onomastycznych, w szczególności w czeskim słowniku imion Jak se bude vaše ditě jmenovat? autorstwa słynnej czeskiej badaczki Miłosławy Knappowej (2017). Jego najnowsza edycja z 2017 roku obejmuje 17000 czeskich i obcych form imion. Każde z tych imion (czeskie lub obce) rodzice mają prawo wybrać dla dziecka, jego obecność w wyżej wymienionym słowniku jest wystarczającym powodem do oficjalnego wpisania imienia. Hasła słownika obok obcojęzycznych przedstawiają również ukraińskie odpowiedniki, które są podstawą badania. W artykule w celu porównania wykorzystano materiał obecny w ukraińskich słownikach imion. Analizy ukraińskich imion w czeskim antroponimikonie dokonano drogą wykorzystania metody opisu językoznawczego oraz metody porównawczej i statystycznej. Problem funkcjonowania ukraińskich imion w Republice Czeskiej komplikuje fakt, że język ukraiński posługuje się cyrylicą, a czeski - łaciną. Zasady przekazywania ukraińskich nazw własnych, pisanych cyrylicą, za pomocą zasobów czeskiej grafiki podane są w Przepisach czeskiej pisowni. W artykule stwierdzono, że Przepisy czeskiej pisowni skutecznie przekazują ukraińskie imiona, dzięki czemu mogą być bezpiecznie stosowane. Artykuł analizuje różne problemy, które pojawiają się, gdy ukraińskie imiona są przekazywane za pomocą czeskiej grafiki. Zwrócono uwagę na problem przekazu w imionach ukraińskiej litery z, osobliwości przekazu liter 
$u$ i $i$ oraz zapisywanie miękkości spółgłosek ukraińskich. Dokonano analizy przekazu ukraińskiej litery $\epsilon$ i problemu przeniesienia jotacji w ukraińskich imionach. Wskazano na częstotliwość używania badanych imion w ukraińskim antroponimikonie. Zasugerowano propozycję ewentualnego rozszerzenia repertuaru ukraińskich odpowiedników imion w czeskim słowniku imion w przyszłości. W wyniku dokonanej analizy ustalono, że repertuar imion ukraińskich, który jest reprezentowany w czeskim słowniku imion, jest bardzo bogaty i różnorodny: mieści się w nim 409 męskich imion ukraińskich i 271 żeńskich imion ukraińskich. Spośród nich odnotowano w ukraińskich słownikach imion, odpowiadające im w ukraińskiej pisowni nazwy - 305 imion męskich i 215 żeńskich.

Słowa kluczowe: imię, słownik imion, pisownia, czeski antroponimikon, ukraiński antroponimikon

Article submission date: 28.02.2019

Date qualified for printing after reviews: 03.10.2019 